matous than from non-trachomatous subjects. Overt bacterial conjunctivitis was rare, and there was no clcar evidence that these micro-organisms affected the course of trachorna.

In the soarch for methods of preventing bacterial contamination of chick embryos inoculated with conjunctival scrapings, it was found that neomycin was much more effoctive than streptomycin. Unlike polymyxin $B$, neomycin did not appear to inhibit the growth of TRIC agents. A TRIC agent from the eye of a new-born baby, and one from its mother's genital tract, grew unusually readily in mouse brain. Attempts to use hydrocortisone as a 'provocative test' in cascs of suspected trachoma wero unsuccessful. Neither skin tests nor complement fixation tests with group antigen were found to be useful in the diagnosis of trachoma. Tests of the survival time of trachoma agent on cloth suggest that recently infected fomites may be a source of infection. Attempts to isolate TRIC agent by direct inoculation of known viruspositive conjunctival material into HeLa cells were unsuccessful. Cytological examination of conjunctival serapings from 180 consecutive subjects with and without trachoma showed that active trachoma was usually characterized by degenerative changes in the epithelial cells, and by the presence of polymorphs and lymphocytes in quantity. Plasma cells occurred more frequently in the earlicr stages of the disease. 'The conjunctival cytology returned to normal with the onset of healing.

\title{
CHEMICAL ENGINEERING EDUCATION AND PRACTICE
}

\begin{abstract}
$A$ SECOND Survey of Chemical Engineering Education and Practice, by R. Edgeworth Johnstone and C. B. Lax, was to discover the academic subjects used by a chemical engincer in tho course of his daily work (Chem. Engr., Lond., 195, CE7; 1966). A previous survey on identical lines was used as a gride in designing the chemical engincoring syllabus at Nottingham University (Johnstone, R. Edgeworth, Trans. Inst. Chem. Eng., 39, 263; 1961).

Not surprisingly, report writing, economics and management are the most frequently used skills, but it is cheering to university teachers to know that scientific and mathematical subjocts account for 69 per cent in the frequency tablo (on right). Of course, this does not tell us what proportion of professional men's time is spent on scionce, but it is good to know that science is not, as we are sometimes told, early abandoned by those in industry.

The present and the earlicr surveys produced very similar results with few changes over the five-year interval; no one is surprised that mathematies and computer programming are now moro frequently used, but it is puzzling that materials science should at present bo less popular.

Table 1 shows a comparison between the survey results and the Institution of Chemical Engineers' standard syllabus Scheme for a Degree Course in Chemical Engineering, of which a revisod form has just been published.
\end{abstract}

\begin{tabular}{|c|c|c|c|c|c|}
\hline & \multirow{2}{*}{\multicolumn{2}{|c|}{ Surveyz }} & \multicolumn{3}{|c|}{ Schemes } \\
\hline & \multirow{2}{*}{\multicolumn{2}{|c|}{ (Relative }} & \multirow{2}{*}{\multicolumn{3}{|c|}{$\begin{array}{l}\text { (Percentage wcightings) } \\
1959\end{array}$}} \\
\hline & & & & & \\
\hline & 1960 & 1965 & & process & Design \\
\hline Chemical engineering science & 42 & 40 & 45 & 49 & 50 \\
\hline Pure science & 20 & 20 & 19 & 18 & 12 \\
\hline Social science & 19 & 19 & 4 & 3 & 3 \\
\hline Communication & 11 & 12 & 11 & 10 & 10 \\
\hline Other engineering science & 5 & 4 & 10 & 3 & 8 \\
\hline \multirow[t]{2}{*}{ Vathematics } & 3 & 5 & 11 & 17 & 17 \\
\hline & 100 & $\overline{300}$ & $\overline{100}$ & 100 & $\overline{100}$ \\
\hline
\end{tabular}

The Surveys and the Schemes give remarkably similar distributions betwcen subjects, except for mathematics and social science; but it is clear that a university course in chemical engineering should have a good deal of mathematics to support the other subjects, and this accounts for its high weighting in the Schemes.

How far such surveys should be used in designing curricula is a matter for debate. The Surveys show us what the practising engineer uses, and the Schemes give the professional body's considered opinion about the curriculum. Let us hope that those who devise curricula will read all this material but not feel constrained by it; they should rather be encouraged to innovate and experiment with now courses. The picture might be a wide variety of courses to meet the differing needs of industry, and to suit the talents of particular teachers in individual schools of chemical engineering.

J. F. DAYidson

\section{REVIEW OF BRITISH ELECTRICAL MANUFACTURE}

$\mathrm{T}$ HE prosidential address of Mr. L. Druequer to the Institution of Flectrical Engineers, delivered on October 7, 1965, took the form of a general review of the British electrical manufacturing industry. While the first part of the address dealt with considerations relating to the industry as a whole, detailed attention was confined to the manufacture and utilization of industrial olectrical machinery, particularly with reference to three basic: industrics-metals, mining and shipbuilding.

Following a brief comment on the historical development of electrical manufacture in the course of which he observod that "Tho advent of the controlled semi-conductor, the thyristor, has sounded the doath-knoll of the d.c. generator", Mr. Drucquer turned to consideration of various statistics of industry during the 10-year period 1953-63. Considering first the numbers of persons omployod in certain industries, the trends throughout the period had bcen, on tho whole, downward for coal, textiles and shipbuilding. Metal manufacture and chemical and allied industries had remained almost constant while the electrical industry had increased fairly stoadily to achieve a 40 per cent growth. This was approximately ten times the percontage growth of the total of all manufacturing industries for the same period.

Comparing the utility services, water, electricity and gas, electricity showed a rise of 21 per cent-more than three times that of the total for the three utilities.

Taking the year 1954 as a basis of 100 , the index of production for electrical manufacture had increased to 167 , a value approached only by the chemical industry with an index of 160 . If, as a measure of productivity, the ratio betwcen the index of production and the number employed in the industry is taken, it is found that the increase for electrice.] manufacture for the 10-year period is 27 per cent-a figure exceeded only by the chemical industry.

Taking the number of persons employed in electrical manufacture divided into electrioal machinery, radio- 